\title{
Isolation and Growth of Psychrophilic Diatoms from the Ice-edge in the Bering Sea
}

\author{
By CHASE VAN BAALEN* AND RITA O'DONNELL \\ University of Texas Marine Science Institute, Port Aransas Marine Laboratory, Port Aransas, \\ Texas 78373, U.S.A.
}

(Received 14 October 1982)

\begin{abstract}
Five pure cultures of diatoms, Thalassiosira sp., Navicula sp., Nitzschia sp., and two closely related Chaetoceros spp., were isolated from enrichment cultures made from ice and water samples from the ice-edge in the Bering Sea. Four cultures were studied in detail. The isolates did not grow above $18^{\circ} \mathrm{C}$; optimum growth was from 10 to $14{ }^{\circ} \mathrm{C}$. The Nitzschia sp. and Chaetoceros spp. grew reproducibly at $0 \pm 0 \cdot 2^{\circ} \mathrm{C}$, albeit with long generation times of 6 to $7 \mathrm{~d}$. Generation times at $10^{\circ} \mathrm{C}$ were 0.8 to $1.9 \mathrm{~d}$. The long generation times at $0^{\circ} \mathrm{C}$ appeared intrinsic; growth rates were not increased by addition of ammonia, complex organic hydrolysates or light and dark cycles. The elemental analysis and culture density of the algae were reasonable. For example, the elemental analysis of Nitzschia sp. grown at $0{ }^{\circ} \mathrm{C}$ was $\mathrm{C}$, $34.51 \% ; \mathrm{H}, 5.00 \% ; \mathrm{N}, 5 \cdot 12 \%$; ash, $30.3 \%$, very similar to the values for cells grown at $10^{\circ} \mathrm{C}$. Cell yields of $0.5 \mathrm{mg}$ dry weight $\mathrm{ml}^{-1}$ were routinely achieved. These appear to be among the first pure cultures of psychrophilic diatoms and possibly of microalgae in general.
\end{abstract}

\section{INTRODUCTION}

Our perception of the physiology and biochemistry of microalgae rests largely upon work with mesophilic strains. However, it has been known for many years that a rich assemblage of microalgae, primarily diatoms and small flagellates, is associated with the underside of the sea ice, the so-called ice algae (Bunt \& Wood, 1963; Dunbar, 1975; Horner, 1976; Saito \& Taniguchi, 1978). These ice forms are believed to be important contributors to the primary production of the polar regions (Bunt, 1963; McRoy \& Goering, 1974). In the Bering Sea the ice algae comprise the first spring bloom, well preceding blooms that occur in the open water further south (McRoy \& Goering, 1974). As a first step towards understanding adaptations of psychrophilic algae we isolated five pure cultures of diatoms from water and ice samples taken at the ice-edge in the Bering Sea, in February-March, 1981 (Pease \& Muench, 1981). Here we describe characteristics of photoautotrophic and heterotrophic growth of these cultures.

\section{METHODS}

Sample collection, enrichment cultures and isolation. Samples were collected from water pumped from the bow intake system of the R/V Surveyor, from melted ice cores, or from small pieces of floating, brown-coloured ice. The samples were submitted to enrichment culture within $1 \mathrm{~h}$ of collection. The medium for the enrichment cultures was a 50:50 mixture of filtered $(0.4 \mu \mathrm{m})$ local sea water and a synthetic algal medium, KASP-2, derived from medium ASP-2 (Van Baalen, 1962). Medium KASP-2 contained, per litre of glass distilled water: $18 \mathrm{~g} \mathrm{NaCl}$; $5 \mathrm{~g} \mathrm{MgSO}_{4} .7 \mathrm{H}_{2} \mathrm{O} ; 0.60 \mathrm{~g} \mathrm{KCl} ; 0.37 \mathrm{~g} \mathrm{CaCl}_{2} .2 \mathrm{H}_{2} \mathrm{O} ; 1 \mathrm{~g} \mathrm{NaNO} ; 0.05 \mathrm{~g} \mathrm{KH}_{2} \mathrm{PO}_{4} ; 1 \mathrm{~g}$ Tris; $0.03 \mathrm{~g}$ EDTA, disodium salt, dihydrate; $0.004 \mathrm{~g} \mathrm{FeCl}_{3} .6 \mathrm{H}_{2} \mathrm{O} ; 0.034 \mathrm{~g} \mathrm{H}_{3} \mathrm{BO}_{3} ; 0.004 \mathrm{~g} \mathrm{MnCl}_{2} .4 \mathrm{H}_{2} \mathrm{O} ; 670 \mu \mathrm{g} \mathrm{ZnSO}_{4} .7 \mathrm{H}_{2} \mathrm{O}$; $38 \mu \mathrm{g} \mathrm{Na}_{2} \mathrm{MoO}_{4} .2 \mathrm{H}_{2} \mathrm{O} ; 12 \mu \mathrm{g} \mathrm{CoCl}_{2} .6 \mathrm{H}_{2} \mathrm{O} ; 0 \cdot 3 \mu \mathrm{g} \mathrm{CuSO}_{4} .5 \mathrm{H}_{2} \mathrm{O} ; 0 \cdot 125 \mathrm{~g} \mathrm{Na}_{2} \mathrm{SiO}_{3} .5 \mathrm{H}_{2} \mathrm{O}, 300 \mu \mathrm{g}$ thiamin; $8 \mu \mathrm{g}$ vitamin $\mathrm{B}_{12} ; 30 \mu \mathrm{g}$ biotin. The enrichment cultures were incubated in continuous light at -1 to $0{ }^{\circ} \mathrm{C}$ in the shipboard flowing water system (one overhead fluorescent fixture) or at 5 to $7^{\circ} \mathrm{C}$ in a refrigerator (one $40 \mathrm{~W}$ tungsten lamp). The cultures were frequently examined microscopically and transferred to fresh medium as appropriate. Unialgal cultures were purified by repeated streaking on Petri dishes containing medium composed of a 50:50 mixture of offshore Gulf of Mexico sea water and medium KASP-2, plus 1\% agar (low gelling 
temperature agar, no. A4018; Sigma). The dishes were incubated in continuous fluorescent or tungsten light in sealed plastic containers in an atmosphere of 0.5 to $1 \% \mathrm{CO}_{2}$ in air at 5 or $10^{\circ} \mathrm{C}$. After 5 to $15 \mathrm{~d}$ suitable microcolonies were excised, transferred to agar slants, and examined for purity microscopically and in KASP-2 medium supplemented with complex organic materials: $0 \cdot 1 \%$ each of yeast extract, Casamino acids, and soytone (Difco). Stock cultures were routinely maintained as slants in a refrigerator at 5 to $10^{\circ} \mathrm{C}$ and illuminated by one $40 \mathrm{~W}$ tungsten lamp 25 to $40 \mathrm{~cm}$ from the cultures.

Light-temperature gradient plate. The aluminium plate was $46 \times 63.5 \times 1.27 \mathrm{~cm}$ (Van Baalen \& Edwards, 1973). It was illuminated by two rows (two lamps per row placed end to end) of F20T12WWX fluorescent lamps placed $34 \mathrm{~cm}$ above the front edge. The light intensity measured at the position of the front row of Petri dishes was $420 \mu \mathrm{W} \mathrm{cm} \mathrm{cm}^{-2}$ (model 65 Radiometer, YSI Co., Yellow Springs, Ohio, U.S.A.). Pyrex Petri dishes, $60 \times 15 \mathrm{~mm}$, containing $10 \mathrm{ml}$ medium ( $50: 50 \mathrm{KASP}-2$ and sea water) plus the inoculum were placed at desired locations on the plate. Growth was judged visually, or, if dense enough, by a turbidity measurement.

Liquid cultures. Cultures were grown in Pyrex test tubes, $22 \times 175 \mathrm{~mm}$, containing $20 \mathrm{ml}$ medium. They were illuminated by F20T12WWX fluorescent lamps $10 \mathrm{~cm}$ from the lamp centre to the centre of the test tube. Lamp output was cut to approximately $60 \%$ by one copper screen inserted between the lamps and the growth bath. The bath temperatures were held to $\pm 0.2{ }^{\circ} \mathrm{C}$ at $0{ }^{\circ} \mathrm{C}$ and $\pm 0.5^{\circ} \mathrm{C}$ at $10^{\circ} \mathrm{C}$. The cultures were continuously bubbled with $1 \pm 0.1 \% \mathrm{CO}_{2}$ in air. Cell concentration was measured turbidimetrically or by dry weight. The cells were collected on a $0.4 \mu \mathrm{m}$ Nucleopore filter (Nucleopore Corp., Pleasanton, Calif., U.S.A.), gently washed with distilled water, dried at $45^{\circ} \mathrm{C}$ in a vacuum oven over $\mathrm{P}_{2} \mathrm{O}_{5}$ and weighed.

Heterotrophic growth. The substrates were absorbed on sterile, washed, antibiotic discs $(12.7 \mathrm{~mm})$ and placed on seeded $\left(10^{5}\right.$ c.f.u. $\left.\mathrm{ml}^{-1}\right) 100 \times 15 \mathrm{~mm}$ plastic Petri dishes. The medium was 50:50 KASP-2 and sea water; the plates were quickly poured at $31{ }^{\circ} \mathrm{C}$ using the low gelling temperature agar described above. The plates were wrapped in two layers of aluminium foil and incubated for up to six weeks at 9 to $11^{\circ} \mathrm{C}$ in a refrigerator. The plates were carefully examined both visually and microscopically for growth.

\section{RESULTS}

The cultures were identified by Professor Qi-Yu-zao of the Department of Biology, Jinan University, Guangzhou, People's Republic of China, as: Thalassiosira sp. (our notation D1-2), Navicula sp. (J-4), Nitzschia sp. (K3-3), Chaetoceros sp. (K3-10 and KD-50). Organisms K3-10 and KD-50 were isolated from two different samples and may be the same species, tentatively $C$. laciniosus Schutt, but they were sufficiently different in response to warrant experimentally being considered two different organisms. It should be noted that these diatoms isolated from the enrichment cultures, while certainly not all the organisms present, were commonly seen in numerous fresh samples examined on shipboard.

The light-temperature gradient plate was used to survey the general growth characteristics of the isolates from 6 to $22^{\circ} \mathrm{C}$ (Fig. 1). All the cultures were clearly cold-adapted. Only one strain, Chaetoceros sp. K3-10, grew well at $18^{\circ} \mathrm{C}$. The optimum temperatures were from 10 to $14^{\circ} \mathrm{C}$. It was not practical to operate the light-temperature gradient plate below $6{ }^{\circ} \mathrm{C}$ nor was the plate useful for measuring growth rates. Growth rates were therefore measured in liquid cultures at 0 or $10{ }^{\circ} \mathrm{C}$ (Table 1). Three of the isolates, $\mathrm{KD}-50, \mathrm{~K} 3-10$ and $\mathrm{K} 3-3$, maintained reproducible generation times at $0{ }^{\circ} \mathrm{C}$ ranging from 5.8 to $6.8 \mathrm{~d}$. At $10^{\circ} \mathrm{C}$ the growth rates were 0.75 to $1.9 \mathrm{~d}$. A fifth isolate, Thalassiosira sp. D1-2 grew at such a slow rate even at $10^{\circ} \mathrm{C}$ as to preclude useful experimental work. Organism K3-3 required vitamin $\mathbf{B}_{12}$. The other cultures grew without added vitamins. Of particular interest were the exceedingly slow growth rates, especially at $0{ }^{\circ} \mathrm{C}$. We searched for chemical or physical factors that might stimulate the growth rate. Light and dark cycles (20L:4D) or addition of reduced nitrogen, $\mathrm{NH}_{4} \mathrm{Cl}$ or organic nitrogen in the form of casein, soy or meat hydrolysates, had little effect. Of the lamp phosphors and intensities screened, the combination of two deluxe warm white fluorescent lamps plus one screen gave the most consistent results with the cultures. Moreover, short-time photosynthesis measurements (as ${ }^{14} \mathrm{CO}_{2}$ fixation) carried out in the same lighting conditions gave linear and saturated rates over several hours. Based upon experience to date, no significant stimulation of growth rate is anticipated from other lamp combinations.

The choice of medium, 50:50 KASP-2 and sea water, was made for the original enrichment cultures; however, in the growth work with the pure cultures sea water could be replaced by distilled water containing $20 \mathrm{~g} \mathrm{NaCl}^{-1}$ or by full-strength $\mathrm{KASP}-2$ medium with the same 


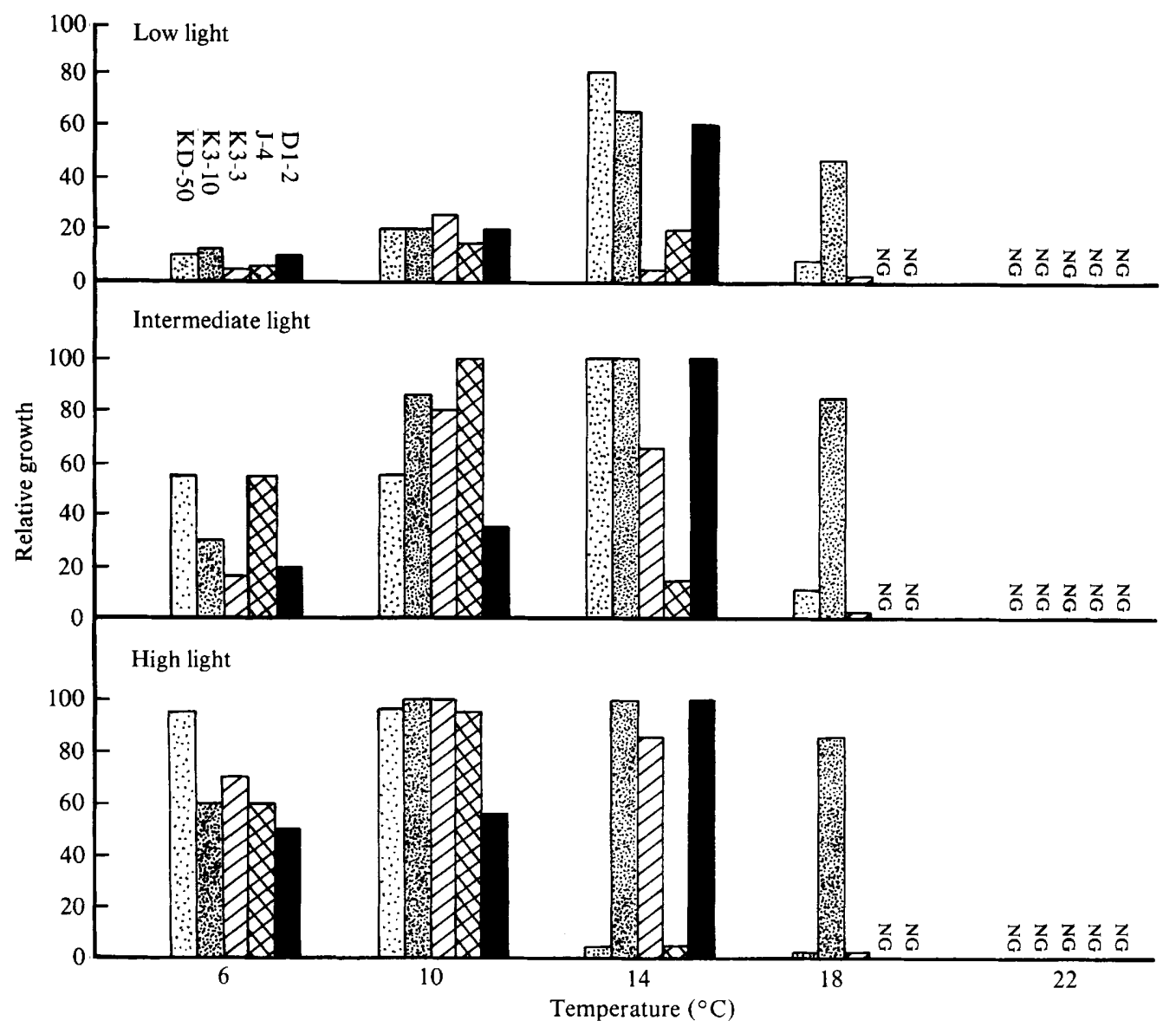

Fig. 1. Relative growth of ice-edge diatoms as a function of temperature and light intensity. For each organism the data were recorded relative to the position on the light-temperature gradient plate which gave the best growth $(=100)$; NG means no growth. The experiments were purposely terminated after 10 to $12 \mathrm{~d}$ at relatively low cell densities to avoid severe $\mathrm{CO}_{2}$ or light limitations on growth. The light intensities at the high, intermediate and low light positions were 19,14 and $8 \mu \mathrm{E} \mathrm{s}^{-1} \mathrm{~m}^{-2}$, respectively (measured with a Li-Cor LI-185A photometer; LiCor, Inc., Lincoln, Nebraska, U.S.A.). The intensities were uniform from side to side.

\section{Table 1. Generation times of psychrophilic diatoms at $0^{\circ} \mathrm{C}$ and $10^{\circ} \mathrm{C}$}

The growth rates were the same with or without one screen between the lamps and the growth tubes, under a $20 \mathrm{~h}$ light $/ 4 \mathrm{~h}$ dark cycle, or with $\mathrm{NaNO}_{3}(10 \mathrm{mM})$ or $\mathrm{NH}_{4} \mathrm{Cl}(2-4 \mathrm{mM})$ as nitrogen sources. The rates shown were reproducible to $\pm 15 \%$.

\section{Strain}

Chaetoceros sp. KD-50

Chaetoceros sp. K3-10

Nitzschia sp. K3-3

Navicula sp. J-4

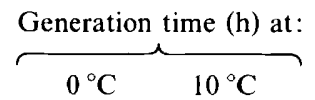

$\begin{array}{ll}165 & 20 \\ 140 & 18 \\ 145 & 38 \\ \text { NG } & 45\end{array}$

NG, No growth.

results. Thus the general availability of nutrients did not seem to be the cause of the slow growth rates. Based upon past experience with mesophilic diatoms, we also varied the silica concentration from 0.5 to 2 times the normal value, again without noticeable effect. We have not 
observed nor did we anticipate any untoward effects on growth from the use of $1 \% \mathrm{CO}_{2}$ enriched air. Limited substitution of air for the $1 \% \mathrm{CO}_{2}$-enriched air gave similar results. In addition, any $\mathrm{CO}_{2}$ effect on algal growth is anticipated at low $\mathrm{CO}_{2}$ concentrations not at high concentrations (Repaske \& Clayton, 1978).

By two fundamental criteria of algal culture, readily achievable cell yield and elemental analysis, Chaetoceros sp. KD-50 and Nitzschia sp. K3-3 behaved as expected under photoautotrophic growth conditions. Cell yields of $0.5 \mathrm{mg}$ dry weight $\mathrm{ml}^{-1}$ were routinely achieved with each organism. The elemental analyses of organism KD-50 grown at 0 and at $10{ }^{\circ} \mathrm{C}$ were, respectively: $\% \mathrm{C}, 32.29$ and $32.91 ; \% \mathrm{H}, 4.99$ and $4.98 ; \% \mathrm{~N}, 5.16$ and $5.42 ; \%$ ash, 34.9 and 30.9. The elemental analyses of organism K3-3 grown at 0 and at $10{ }^{\circ} \mathrm{C}$ were, respectively: $\% \mathrm{C}, 34.51$ and $34.41 ; \% \mathrm{H}, 5.00$ and $5.04 ; \% \mathrm{~N}, 5 \cdot 12$ and $4.50 ; \%$ ash, 30.3 and $34 \cdot 2$. On an ash-free basis these values compared very favourably with a variety of algal cells (Kok, 1952; Van Baalen \& Marler, 1963; Bottomley \& Van Baalen, 1978). It is also of interest that the calculated protein content (Milner, 1953) from the above analyses ranged from 43 to $49 \%$. Whatever else are the metabolic restrictions imposed on an algal cell growing at $0{ }^{\circ} \mathrm{C}$, the overall product is not grossly different from what we have come to expect from mesophilic or moderately thermophilic forms.

It has been often suggested that 'high-latitude' phytoplankters may have a well-developed capacity for heterotrophic growth, the better to endure long periods of darkness (Allen, 1971). However, of the four psychrophilic diatoms studied only one, Navicula sp. J-4, readily grew in the dark on glucose with nitrate as nitrogen source. J-4 also grew on casein hydrolysate (Matheson, Coleman, Bell, Inc., East Rutherford, N.J., U.S.A.) alone albeit at a much slower rate than on glucose. The other organisms, KD-50, K3-10 and K3-3, did not grow on glucose, lactate, glycerol or malate with nitrate as nitrogen source or in combination with Casamino acids. Furthermore, organism $J-4$ was the only culture which responded to protein digests such as N-Z Case, Primatone, Edamin and Hy-Soy (Sheffield Products, Kraft Inc., Memphis, Tenn., U.S.A.). Although only four pure cultures were studied in detail, their lack of a well-developed heterotrophy argues against this specialization being common in Arctic and perhaps also in kindred Antarctic phytoplankters.

\section{DISCUSSION}

Several interesting features emerge from the characterization of growth in these ice-edge diatoms. First, these organisms fit the textbook definition of obligate psychrophiles, microorganisms that can grow well at $0{ }^{\circ} \mathrm{C}$ and that do so optimally below $20^{\circ} \mathrm{C}$ (Ingraham \& Stokes, 1959; Inniss, 1975; Morita, 1975). Their second significant characteristic was their exceedingly slow measured generation times, 6 to $7 \mathrm{~d}$ at $0{ }^{\circ} \mathrm{C}$. Such very slow generation times were not anticipated from the existing large body of information primarily on mesophilic microalgae (Van Baalen, 1974). Indeed, a theoretical treatment of algal growth rates versus temperature predicted generation times approaching $1 \mathrm{~d}$ at $0{ }^{\circ} \mathrm{C}$ (Eppley, 1972). In work with unialgal cultures of four Arctic ice diatoms at $5^{\circ} \mathrm{C}$ generation times of 1 to $2 \mathrm{~d}$ were found (Grant \& Horner, 1976). A unialgal strain of Skeletonema costatum, a typical mesophilic form, had an estimated generation time of approximately $2 \mathrm{~d}$ at $0^{\circ} \mathrm{C}$ (Yoder, 1979).

The generation times measured by us at $0{ }^{\circ} \mathrm{C}$ with pure cultures of psychrophilic diatoms appear to be the first of their kind. The lack of response of these forms to ammonia or complex organic nitrogen sources suggested that nitrogen assimilation was not limiting growth. We speculate that growth was limited by rate of carbon assimilation. Along these lines, ribulose-1,5bisphosphate carboxylase-oxygenase can undergo a reversible cold inactivation (Chollet \& Anderson, 1977) or changes in properties in 'cold-hardened' rye plants (Huner \& MacDowall, 1979). In wheat leaves it was suggested that the carboxylation of ribulose 1,5-bisphosphate was suppressed at low temperatures, leading to increased formation of glycine and serine through the glycolate pathway (Sawada \& Miyachi, 1974). We are investigating the possibility that the very slow growth rate at $0{ }^{\circ} \mathrm{C}$ of these psychrophilic diatoms is related to one or more of these changes in ribulose-1,5-bisphosphate carboxylase-oxygenase. 
We are grateful to Captain Bruce Williams and the crew of the R/V Surveyor for their invaluable help in collecting the samples. We thank Seelye Martin for providing several ice cores and Professor Qi for his help in identifying the cultures. This study was funded in part by the Bureau of Land Management through interagency agreement with the National Oceanic and Atmospheric Administration, as part of the Outer Continental Shelf Environmental Assessment Program. The elemental analyses were performed by Galbraith Laboratories, Inc., Knoxville, TN 37921, U.S.A.

The University of Texas Marine Science Institute Contribution no. 558.

\section{REFERENCES}

ALLEN, M. B. (1971). High-latitude phytoplankton. Annual Review of Ecology and Systematics 2, 261-276.

Bottomley, P. J. \& Van BaAlen, C. (1978). Characteristics of heterotrophic growth in the blue-green alga, Nostoc sp. strain MAC. Journal of General Microbiology 107, 309-318.

BUNT, J. S. (1963). Diatoms of the sea-ice as agents of primary production. Nature, London 199, 1255-1257.

BUNT, J. S. \& WoOD, E. J. F. (1963). Microalgae and Antarctic sea-ice. Nature, London 199, 1254-1255.

Chollet, R. \& Anderson, L. L. (1977). Conformational changes associated with the reversible cold inactivation of ribulose-1,5-bisphosphate carboxylase-oxygenase. Biochimica et biophysica acta $\mathbf{4 8 2}$, 228-240.

Dunbar, M. J. (1975). Biological oceanography in Canadian Arctic and sub-arctic waters. Journal of the Fisheries Research Board of Canada 32, 2276-2283.

EPPLEY, R. W. (1972). Temperature and phytoplankton growth in the sea. Fishery Bulletin 70, 1063 1085.

Grant, W. S. \& Horner, R. A. (1976). Growth response to salinity variation in four Arctic ice diatoms. Journal of Phycology 12, 180-185.

HORNER, R. S. (1976). Sea ice organisms. Oceanography and Marine Biology Annual Reviews 14, 167-182.

Huner, N. P. A. \& MacDowall, F. D. H. (1979). Changes in net charge and subunit properties of ribulose bisphosphate carboxylase-oxygenase during cold hardening of Puma rye. Canadian Journal of Biochemistry 57, 155-164.

IngRahaM, J. L. \& STOKES, J. L. (1959). Psychrophilic bacteria. Bacteriological Reviews 23, 97-108.

INNISS, W. E. (1975). Interaction of temperature and psychrophilic microorganisms. Annual Review of Microbiology 29, 445-465.

KoK, B. (1952). On the efficiency of Chlorella growth. Acta botanica neerlandica 1, 445-467.

McRoy, C. P. \& Goering, J. J. (1974). The influence of ice on the primary productivity of the Bering Sea. In Oceanography of the Bering Sea, pp. 403-421. Edited by D. W. Hood \& E. J. Kelley. Fairbanks: University of Alaska Occasional Publication No. 2.
MilNer, H. W. (1953). The chemical composition of algae. In Algal Culture from Laboratory to Pilot Plant, pp. 285-302. Edited by J. S. Burlew. Washington, D.C. : Carnegie Institution of Washington Publication 600 .

MORITA, R. Y. (1975). Psychrophilic bacteria. Bacteriological Reviews 39, 144-167.

Pease, C. H. \& Muench, R. D. (1981). Cruise along the ice edge in Bering Sea yields data on effects of gale. Coastal Oceanography and Climatology News (University of Rhode Island, Kingston) 3, 43-45.

Repaske, R. \& Clayton, M. A. (1978). Control of Escherichia coli growth by $\mathrm{CO}_{2}$. Journal of Bacteriology 135, 1162-1164.

SaIto, K. \& TANiguchi, A. (1978). Phytoplankton communities in the Bering Sea and adjacent areas. II. Spring and summer communities in seasonally ice-covered areas. Astarte 11, 27-35.

SAWADA, S. \& MiYaCHI, S. (1974). Effects of growth temperature on photosynthetic carbon metabolism in green plants. II. Photosynthetic ${ }^{14} \mathrm{CO}_{2}$-incorporation in plants acclimatized to varied temperatures. Plant and Cell Physiology 15, 225-238.

VAN BAALEN, C. (1962). Studies on marine blue-green algae. Botanica marina 4, 129-139.

VAN BAALEN, C. (1974). Growth, photosynthetic, and respiratory rates of the microalgae. In Handbook of Microbiology, pp. 21-28. Edited by A. I. Laskin \& H. A. Lechevalier. Cleveland, Ohio: CRC Press.

Van BaAlen, C. \& Edwards, P. (1973). The lighttemperature gradient plate. In Handbook of Phycological Methods, Culture Methods and Growth Measurements, pp. 267-274. Edited by J. R. Stein. Cambridge; Cambridge University Press.

Van BaAlen, C. \& Marler, J. E. (1963). Characteristics of marine blue-green algae with uric acid as nitrogen source. Journal of General Microbiology 32, 457-463.

YODER, J. A. (1979). Effect of temperature on lightlimited growth and chemical composition of Skeletonema costatum (Bacillariophyceae). Journal of Phycology 15, 362-370. 